\title{
Aristotle on the Good Man's Desire for Pleasant Friends
}

\author{
Andreas Vakirtzis
}

\begin{abstract}
At $N E$ 1158a22-27, Aristotle argues that the virtuous man will pursue friendships with pleasant people, but not with people who are useful to him. Ideally, he adds, these friends should, despite being pleasant, also be good, since, in this manner, the good man would have all the goods of friendship. The main problem with this passage is that the good man desires his friends to be pleasant; or, put it otherwise, that he desires pleasant friends. This idea, however, stands on the opposite side of Aristotle's axiological hierarchy where the virtuous man desires, first and foremost, the good, both as a goal in his life as a whole and in his friends, in particular. Pleasure is valuable for Aristotle's ethics, but it only comes second to virtue and the good. In the present paper, I will defend Aristotle, by arguing that he may justify the argument of this passage without though jeopardizing his precious axiological hierarchy.
\end{abstract}

\section{Introduction}

At $N E^{1}$ 1158a22-27, Aristotle argues that the virtuous man will pursue friendships with pleasant people, but not with people who are useful to him. Ideally, he adds, these friends should, despite being pleasant, also be good, since, in this manner, the good man would have all the goods of friendship.

The main problem with this passage is that the good man desires his friends to be pleasant; or, put it otherwise, that he desires pleasant friends. This idea, however, stands on the opposite side of Aristotle's axiological hierarchy where the virtuous man desires, first and foremost, the good, both as a goal in his life as a whole and in his friends, in particular. Pleasure ${ }^{2}$ is valuable for Aristotle's ethics, but it only comes second to virtue and the good.

In the present paper, I will defend Aristotle, by arguing that he may justify the argument of this passage without though jeopardizing his precious axiological hierarchy. To this purpose, I will provide the following reasons:

\footnotetext{
${ }^{1}$ Ethica Nicomachea.

${ }^{2}$ Pleasure is one of the most important concepts in Aristotle's ethics. It is actually a crucial element of various topics in the $N E$ such as the development of the moral character, virtues, vices, eudaimonia, akrasia, and more. For a very good analysis of some of the most prominent issues regarding pleasure-and especially the conflict between NE VII 11-14 and X 1-5-see Verity Harte's (2014: 288-319) recent essay, "The Nicomachean Ethics on Pleasure".
} 
(1) Character friendship is ideal for the virtuous agent. This kind of friendship, however, takes place extremely rarely. The reason for this is that it is unusual for two people to have reached the same level of highly developed moral goodness. Therefore, it is rather unlikely for a good man to meet and befriend another agent as good as he is.

(2) If (1) is true then if the good man does not want to remain friendless he must pursue friendships which are valuable, yet, not the most valuable in Aristotle's axiological hierarchy. In this section, I will argue that this desire derives, largely, from the good man's social and political nature. By this, I mean that he desires, by nature, to share his life with others, and especially with friends. But this is merely the initial spark that impels the agent to pursue other forms of friendship than the one that occurs between good people.

(3) In this third section I will clarify how it is likely for the good man to desire pleasant friends without, however, this fact influencing his axiological hierarchy. I will suggest that the virtuous agent does not consider pleasant just anyone. He values others as pleasant, only if he recognizes in them at least some good habits of character which are manifested by the activities that they have chosen to take part in, such as athletic activities, music, theater, and other cultured activities.

The difference though between the virtuous agent and his friend rests on why each one of them values these activities, and each one's attitude towards these activities. On the one hand, the virtuous agent values them as being worthy of doing, and as being part of the good life and eudaimonia. Nevertheless, he does not deviate from his attribute of valuing virtuous activity higher than any other kind of activity. In contrast, his friend enjoys them for being what they are in that they fulfill his life as such, in the sense that he engages, in one or more of these activities, more devotedly than the good man does. Moreover, this dissimilarity between the two friends, with regard to the reason that they value these activities, is manifest in their attitude towards them as well. That is, while the virtuous agent ${ }^{3}$ will not engage in them with excess, his pleasant friend probably will; and this reflects the differences between them concerning their moral characters.

I will deploy the present paper in the following order. In the first section, I will discuss the problems that arise from the passage at $N E$ 1158a22-27. In sections 2, 3, and 4, I will analyze the three corresponding reasons that support my defense of Aristotle. In the last section, I will conclude the present paper.

\section{The Passage at NE 1158a22-27}

The passage from the Nicomachean Ethics that is the most ${ }^{4}$ significant for our purposes in the present essay is the following:

\footnotetext{
${ }^{3}$ Henceforward VA.

${ }^{4}$ I will mainly focus on this passage in the present paper, but I want to note that Aristotle expresses the idea regarding the good agent's desire for pleasant friends in other passages of the $N E$ as well. For instance, at $N E$ $1169 \mathrm{~b} 24-5$, he says that the blessedly happy man will not need friends who are useful to him since he already has the things, which are good. In addition, he goes on to argue "...he will not need friends because of pleasure, or perhaps to a small extent. This is so because his life is already pleasant and he, therefore, does not need any imported pleasure" (NE 1169b25-7).
} 
The blessed ${ }^{5}$, too, though they have no need of useful friends, they do need pleasant ones. For they wish to spend their lives in the company of others, and while they can bear what is painful for a short time, nobody could endure it continuously-not even the Good Itself, if it were painful to him. This is why they seek friends who are pleasant. Nevertheless, presumably ${ }^{6}$ they ought to seek friends who are good as well and good for them, because they will then have what friends should have. (NE 1158a22-7)

The first thing that someone may notice in this passage ${ }^{7}$ is that the VA does not need useful friends, yet he needs pleasant ${ }^{8}$ ones (NE 1158a22). This must mean that because pleasure friendship is axiologically closer to character friendship, it is, thereby, more valuable than utility friendship. Broadie $^{9}$ puts it nicely when she says "the principle is: for any two sub-types, F1 and F2, the one more closely linked with the supreme good is closer to being exemplary of the type."

The idea regarding utility friends is that since they are not pleasant to the VA then it must be painful to live with them. Hence, it makes sense for him not to choose them to be his friends. The main reason for not choosing them is, of course, that they are not virtuous. Nevertheless, the fact that if he chose them it would be painful also plays a significant role, especially in view of the fact that no virtue is involved in them anyway. In our case of pleasant friends, however, the VA's friend is pleasant to him due to, as we will be seeing shortly in the present paper, the worthy activities that he chooses to be involved in.

We may find a second interesting idea at $N E$ 1158a24-25. Aristotle says here that the blessed man would not even stand the Good itself, if it were painful. This passage reminds us of the Philebus. Plato argues there that if the chief good were comprised of wisdom, without even a small part of pleasure, then it would not be a good that a human would pursue (Philebus 21d-e). This implies that even the good man needs sources of pleasure, in order to live a more fulfilled life. Of course, in the text that is of interest to us in the Nicomachean Ethics, Aristotle is consistent with this position by saying, as we saw, that the VA should preferably try to find friends who are good and

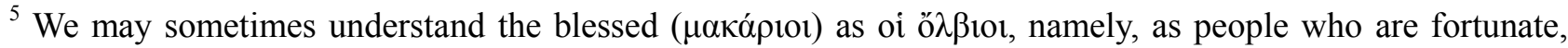
rich, better educated, etc. In other words, someone could complain here that the blessed is distinct from the eudaimon, and hence, the good man. Nevertheless, this is not true. The two terms are deeply related, and this is evident by the fact that Aristotle uses them almost interchangeably at $N E$ IX.9, where he wonders whether the eudaimon person will need friends or not. See also footnote 3 .

${ }^{6}$ This '̈ $\sigma \omega \varsigma$ here unveils Aristotle's intentions in this passage. The point is that the friends that the good man seeks should, also be good, apart from being pleasant. Aristotle, however, must have realized the difficulties of this endeavor; that is why he implies that, even though this should be the ideal, it is very difficult for someone to achieve this.

${ }^{7}$ It is noteworthy, that the problem concerning this passage that I am trying to address in the present paper has been neglected in the literature.

${ }^{8}$ In this passage, Aristotle is consistent with what he says at $N E 1169 \mathrm{~b} 25-7$. He argues there that the good man does not need utility friendships, but he needs pleasant ones. The point is though that pleasure should accompany a good action, and that it should not be my motive for wanting to befriend the other; and this idea was also confirmed by $N E$ 1099a15-23. But Aristotle leaves a small frame for pleasure friendships both at 1158a22-27 and 1169b25-7.
}

${ }^{9}$ Broadie and Rowe (2002: 142). 
pleasant. The idea, however, is that he should look for friends who are pleasant, without them necessarily being good; or, at least, not perfectly good as Aristotle wants his virtuous agents to be.

Additionally, there is a third, and, perhaps, more stimulating idea that is implied by this passage. The idea is that the VA can be friends with people who are pleasant to him. This idea is thorny since it is opposed to Aristotle's axiological hierarchy. Specifically, Aristotle divides what is lovable in three categories: the good, the pleasant ${ }^{10}$, and the useful (NE 1155b18-19, 1104b30-1).

Based on this division, he identifies three major forms of friendship: (a) between good people, (b) between people who are pleasant to each other and, (c) between people who are useful to each other (NE VIII.3). The kind of friendship that is apt for the virtuous agent is (a). In this one, the virtuous agent loves and wishes good things for his friend's sake, namely, for him being virtuous (NE 1156b6-10). One main difference between loving you for who you are, namely, for being virtuous, and loving you for being pleasant or useful to me is that, in the first case, I love you for some essential characteristic you have, while, in the latter case, Aristotle calls these characteristics that we are fond of as incidental.

The point then is that the VA should ideally pursue friendships with other virtuous agents since the predominant desire in his life is the good, and this is what he should look for in his friends, too. So, if he desires someone to be his friend for being pleasant to him then he is rendered unfaithful to the standard of values that constitute the foundations of his virtuous life. The main objective, then, of the following three sections, is to defend Aristotle against these unpleasant arguments. The subsequent, and first out of three sections, will have to do with the rarity of virtuous friendships.

\footnotetext{
${ }^{10} \mathrm{I}$ have to note here that pleasure may not be as valuable as the good, but it is considerably valuable anyway. In Book X of the Nicomachean Ethics, for instance, Aristotle argues that pleasure is $a$ good but not the good. He cites and endorses an argument given by Plato in the Philebus: 'If we imagine a life filled with pleasure and then mentally add wisdom to it, the result is made more desirable. But the good is something that cannot be improved upon in this way. Therefore, pleasure is not the good' (1172b23-35; see also cf. I.7, 1097b14-20; for more details on the Philebus arguments, see 20e-22b and60a-61a.). But, for Aristotle, pleasure acquires its value depending on the activity that it accompanies. Specifically, pleasures are as diverse as activities in kind and in ethical quality ( $N E$ 1175a21-1176a29). For instance, the indulgence in errant pleasures can lead to distortions in the understanding of the proper end of action (NE 1104b31-35; $1113 \mathrm{a} 35 \mathrm{~b} 2 ; 1140 \mathrm{~b} 12-20)$. Also, I have to note here that at the beginning of the Nicomachean Ethics, in his discussion of the three lives, Aristotle says that the life of pleasure is a "life for beasts" and those who choose it are "slavish" (NE 1095b19-20). Nevertheless, this strong disapproval of pleasure seems rather odd and surprising when we consider that at $N E \mathrm{X} .7$ he argues that the life of contemplation is the most pleasant of all. On the other hand, pleasure completes or perfects good activity (NE 1174b14-a21). In this case, pleasure acquires the highest value it can get because it accompanies the highest kind of activity in humans, viz. rational activity. Generally, we should better understand pleasure in view of its connection with goodness (Annas, 1981: 285-299) and rational decision (Broadie, 1991: 331-9). In addition, while Aristotle does not reduce pleasure to the good, he does regard pleasure as that which completes the good (Bostock 1998: 251272; Hadreas 2004: 155-167).
} 


\section{The Rarity of Character Friendships}

In this section, I will discuss Aristotle's view on the rarity ${ }^{11}$ of character friendship, which is expressed in various passages. The first, and perhaps, most noticeable one, can be found at $N E$ 1156b23-32:

And what is good without qualification is also pleasant without qualification; but these things are the most lovable; hence both the love and the friendship are greatest and best among these friends. One should expect such friendships to be rare, since few people are like that. Furthermore, it requires also time and familiarity: as the proverb says, they cannot know each other until they have 'taken salt together'. They cannot accept each other as friends, then, or be friends, until each is plainly seen by the other to be lovable and gains the other's trust. Those who quickly do for each other things characteristic of friendship, though they wish to be friends, in fact are not, unless they are furthermore lovable, and they know this. For although the wish for friendship comes about quickly, friendship does not.

In this passage, Aristotle underlines the rarity ${ }^{12}$ of character friendships. Since few people are as good as Aristotle wants them to be, then there is little chance for two people like that to meet and become friends. This is true because agents need to spend time together and get deeply familiar with each other so that their lovable qualities to be revealed, and, as a result, for their initial and superficial relationship to ripen, eventually, into friendship. It is implied here that if the other agent turns out to be different from what we thought, relating to certain qualities, then our friendship cannot grow any further. In fact, we have reasons to dissolve such a relationship in cases like that. This idea, however, is also connected with the notion of goodwill.

For Aristotle, goodwill is a characteristic of friendship, but it is not friendship, since we can have it towards strangers who do not know about it (NE 1166b30-1). Furthermore, we cannot consider it as loving, because there is no intensity about it, or desire. This happens because the two latter ones go along with loving ( $N E$ 1166b32-3). Loving, as we previously saw, involves familiarity, in contrast to mere goodwill, which can be superficial, sudden, and can arise even for competitors in athletics contests (NE 1166b34-1167a1). As Aristotle notes, however, goodwill can be the beginning of friendship (NE 1167a3-4). It is not friendship, however, since someone can feel goodwill towards someone else and wish good things for him, but, he would not bother joining in his actions, or getting in trouble on his behalf ( $N E$ 1167a8-10). Hence, the idea behind goodwill is that even if we are attracted to someone and feel goodwill towards him, this does not mean that we

\footnotetext{
11 Someone may also check Irwin's (1999: 279) comment on 1158a15ff; he says: "The remark is closely connected with the rarity of good people. Since a person's goodness does not become clear at once, we need both experience (over some length of time) and familiarity (in many situations). Since it is difficult to have the right experience and familiarity with many people, the relevant kind of friendship cannot extend to many people."

${ }^{12}$ Aristotle has already stated at $N E 1156 \mathrm{~b} 24-5$ that very few persons are good. At $N E 1156 \mathrm{~b} 23-32$, this idea is applied to the case of character friendship.
} 
have befriended him yet. To put it another way, in spite of the fact that we might feel goodwill towards someone, it takes more than that for this feeling to eventually grow into a desire for the other as being our friend.

There is a last point I want to stress before I proceed to discuss certain objections against the argument of the present section. At 1158a13-14, Aristotle's idea seems to be that of all the many people we meet, not only few of them will be pleasant enough for us to desire to spend time with them, but, also, even fewer will, in the end, become our friends. This argument should be understood in a similar way as the one that has to do with the rarity of character friendships. The idea here though is that it turns out that it is not an easy task for a valuable pleasure friendship to be formed as well. Perhaps Aristotle means, not only that it takes time and familiarity for a superficial relationship to evolve into friendship, but, also, that even though we will meet many people in our lives who are pleasant to us, few of them will, ultimately, be pleasant enough to us in order to pursue a deeper relationship with them.

The second point I want to make is that in this passage it is implied that those who are not good in character should be avoided all the way (cf. IX.3, 1165b15). The idea of this implication seems to be that the good man should avoid bad people to be his friends; he should pursue pleasure friendships nevertheless. My thoughts regarding this passage will be better unveiled and explored in the third major section of the present essay, where I will explain in what way a pleasant friend can be suitable for the good man. Before moving on, though, let me first consider two possible objections regarding the argument in this section. The first one has to do with a passage at $N E$ 1158a33-4, and the second has to do with the fact that the rarity of friends is no problem at all, since we are supposed to have few friends anyway. Let me begin with the second objection.

According to it, the fact that character friends are rare would not be a problem for the VA since we are supposed to have few friends. Even though this objection stresses an intuitive point, it does not create serious problems for the argument at hand. The reason for this is that the VA knows that he should have few friends, since, only in this fashion, can he share his life with those few people with whom he has similar interests, character traits, etc. Only with few people can, indeed, the VA deepen the relation and build trust. It is impossible, as experience teaches us, to have many friends, and yet be able to have a deep relationship with all of them. Nevertheless, exactly because he is supposed to have few friends, the rarity of character friends is a problem for the VA. He could be spending a lifetime looking for these few people that could be suitable to his level of character, and yet it is highly possible that he would fail finding them. Therefore, the point is, as I argue in the present paper, that he should befriend pleasant people in the way that I analyze especially in section 3.

Concerning now the first objection, Aristotle says at NE 1158a33-4. Let us see though the 
whole argument ( $N E$ 1158a33-36) and not just this small portion of it:

Though we have indeed said that the good person is both pleasant and useful at the same time, he does not become a friend to a superior unless the latter is superior in virtue as well; otherwise he does not attain equality by being proportionately inferior. But superiors like this are rare.

In this passage, Aristotle tries to answer to an objection. Specifically, someone could object that friends of the preeminent, or powerful, man are at the same time useful and pleasant to him. But virtuous men are, simultaneously, pleasant and useful to others. Aristotle responds, however, that the good man will become friends with someone who is eminent in power or resources only if he is surpassed in virtue by the eminent in power. If this does not occur, then the more prevailing figure in power who is surpassed in virtue will not be able to make himself proportionately equal, namely, he will not be able to give proportional compensation to the good man. Specifically, as the good man concedes to him and the more powerful one, in like manner, the powerful one should defer to the good man as the better one of the two.

The problem that the first objection raises against the "rarity argument" is, perhaps, that the VA would have other chances for valuable friendships without getting into the complications of a pleasure friendship. In fact, the VA could become friends with another, eminent in power agent, who surpasses him in virtue. He does not, in other words, have to find someone who equals him in virtue in order to become friends with him. So, he can even have friends as this one; and, in connection with objection (2) that we previously saw, he could be one of those few valuable friends that he shares his life with, without having to be expecting, hopelessly, to find an equal to himself to befriend. The problem though with this objection is that, even though it makes a good point, Aristotle points out that these kinds of friendship between the VA and a powerful man are rare, exactly because superiors, like the one he describes at $N E$ 1158a33-36, are rare. And, I want to underscore the fact that superiors like that in virtue, are even more uncommon to find than someone who is, more or less, as virtuous as the VA is. Therefore, I do not think that his objection is an obstacle to the "rarity argument".

\section{The Political Nature of the Good man and the desire for Pleasure Friendships}

So far, we have seen, roughly, that it is rare for the good man to meet another agent who is virtuous, like himself, and thus pursue to befriend him by start spending time with him and trusting him. But as I said at the introduction, this cannot stand alone as a sufficient reason in justifying Aristotle's claim that the good man will pursue pleasure friendships. Hence, we need to dig a little deeper so that we can better defend Aristotle.

To offer this deeper explanation I will refer to a fundamental idea that we witness in 
Aristotle's ethical and political writings. He claims, in particular, that man is by nature a political ${ }^{13}$ animal. ${ }^{14}$ We may find some representative illustrations of this idea in a number of passages. ${ }^{15}$ For instance, at NE IX.9 1169b17-19 he says, "No one would choose to be by himself and have all of the goods, for a human being is political and by nature lives with others." In other words, humans, and even more so the best ones, will not choose a solitary way of living even if they have all the goods in life. Aristotle implies here that human's natural place is living with others.

Now, in another passage, in his Politics this time, he says, "It has been said in our first discourses...that by nature human beings are political animals. That is why, even when they do not need assistance from each other, they have no less of a desire to live together." (Pol. III.6 1278b1721) What Aristotle says here is even more important than what he says at NE IX.9 1169b17-19. The key idea is not only that humans are by nature political animals; Aristotle also puts emphasis on the fact that even if people do not need assistance from each other, they still desire to live and spend their time together. This means that living with others does not necessarily come out of need for them, but out of an inherent desire to be part of a community; out of a natural desire, in other words, to share their lives and existence with others.

Now, I want to stress one last point before I end this section. The point has to do with the fact that humans are by nature political animals. As we have already seen though this claim seems to have more of a political, rather than a personal resonance. But this does not seem right. We should take Aristotle to mean that this claim holds for both scopes, rather than, for just one of the two. Of course, we cannot disregard the teleological purpose of his claim, in the sense that humans realize their nature inside a polis. Additionally, however, we should not fail to notice the fact that Aristotle lays great emphasis on personal relationships throughout books 8 and 9 of the Nicomachean Ethics, which he generically calls friendships; and these are very important for the agent's life regardless of whether someone is completely virtuous or not. In other words, friends are necessary for various levels of our daily life as, for instance, in cases where we are enjoying similar activities together, benefiting them and practicing, thereby, the virtues, and, more generally, sharing our lives with them. At last, we should not overlook the fact that Aristotle considers friends as very important external goods, along with political power and wealth, which are indispensable for the achievement of eudaimonia (NE 1099a31-2). Hence, we should better take Aristotle to mean that humans have a natural need to share their lives with others either in a broad, that is, a political, or in

\footnotetext{
${ }^{13}$ Of course, the idea that human beings are by nature political animals has been sharply opposed by Hobbes (1994) in his great work Leviathan and in his De Cive (1983).

${ }^{14}$ For some of the most interesting papers that have been written on Aristotle's idea that humans are by nature political animals see: Cooper (1990), Kullmann (1991), Mulgan (1974).

${ }^{15}$ But apart from his ethical and political works, this idea can also be found in his biological works such as in Hist. An. I.1 487b33-488a13.
} 
a more personal way where the "or" in this disjunction should be better understood as an inclusive one. The idea then is that Aristotle's claim works for the present paper's argument as well.

Before I move on to the next section, however, I want to briefly examine the possible connection of the concept of civic friendship with the argument I put forward regarding the political nature of man and his consequent desire for social and political ties with other people, and sense of belonging to a cooperative whole that shares common goals.

Aristotle, both in his Political and in his Ethical works, expresses the idea of civic friendship. In the Politics (1280b23-1281a2), he argues that friendship (1280b38) is the source, and expresses the nature, of the specific bond between fellow-citizens; and this bond explains, in turn, the mutual interest and concern that they show for each other's qualities, etc. To be more specific, he says that, in essence, friendship is the deliberate decision to share our lives with others (1280b38-9). Moreover, friendship is responsible for various practices in the polis, such as religious festivals, marriages, brotherhoods, and, generally, all those pursuits in which people share their lives together (1280b36-38). Aristotle gives us though only a little flavor of what he has in mind regarding civic friendship, since he does not explicitly say, in the aforementioned passages that he refers exactly to this kind of friendship. Nevertheless, he is more explicit about it in his ethical works.

In both the $E E$ and the $N E$, he refers several times to the term civic friendship (

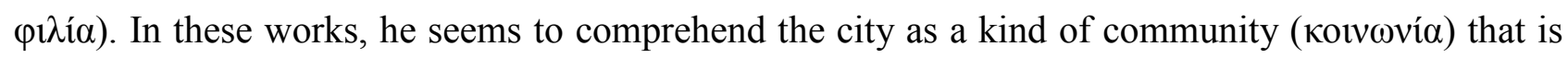
based upon, as Cooper puts it very accurately, "the friendly interest that the citizens take in one another's qualities of mind and character, as well, of course, as upon their common economic interests". ${ }^{16}$ In this kind of a community, as Cooper adds, "the way or ways in which the government seeks to promote the citizens' good as a common good will depend upon the specific character of the friendship that forms the political bond within it, and the ways in which 'civic friends' have and do things in common". ${ }^{17}$

One of the most critical points Aristotle makes about civic friendship, is that it should be considered some sort of advantage friendship. But the argument at NE 1158a22-7, refers strictly to the possibility of pleasure friendships for the blessedly happy man, and discards utility, or advantage, friendships for him. My suspicion then is that at $N E$ 1158a22-7, Aristotle must be referring mainly to personal friendships and, not so much, to political ones. Another reason that grounds this suspicion rests on the following argument that we have already seen in the present section: "It has been said in our first discourses...that by nature human beings are political animals. That is why, even when they do not need assistance from each other, they have no less of a desire to

\footnotetext{
${ }^{16}$ Cooper, 1999, 370.

${ }^{17}$ Ibid., 370.
} 
live together" (Pol. III.6 1278b17-21). This passage is very useful for our purposes, because it gives us space to maneuver regarding the connection of the political nature of man with civic and personal friendships. Namely, the fact that someone's political nature may lead someone to either: (1) be part of a political community where he can cooperate with others in a mutually beneficial way, or, (2) to a simple living together where no mutual beneficence is involved, helps a lot in attributing (2) to $N E$ 1158a22-7, instead of (1). In other words, civic friendship does not seem to play some significant role for the comprehension of the political nature of man, as we want to apply it for the interpretation of Aristotle's argument at NE 1158a22-7.

\section{The Good Man's desire for Pleasant Friends: A defense of Aristotle}

In this last section, I will further defend Aristotle's assertion that the good man will pursue pleasant friends. In particular, having already referred to the two previous reasons that justify his claim, what is left now for us is to explain deeper why is another agent-who is not completely virtuous-pleasant to the good man. In order to address this central issue of the present paper, we first have to answer to certain immediately pertinent and key questions: (1) how should we understand pleasure friendships? (2a) in what way can certain pleasant activities bind together two people who are axiologically different? (2b) what is the difference between the two agents regarding their attitude toward these activities? Let us start with question (1).

With regard to how we should understand pleasure ${ }^{18}$ friendships (1), Aristotle says at $N E$ 1172a3-8:

...hence some drink together, some play dice together, others train, or hunt, or philosophize together, each kind spending their days together in doing whichever of the things in life most satisfies them; for wishing as they do to live a shared life with their friends, they follow and jointly engage in the occupations in which they think they are sharing life with others.

In this passage, we may notice that pleasant ${ }^{19}$ friends spend their time and share their life in

\footnotetext{
${ }^{18}$ Aristotle also provides other, pederast (NE 1156b1-2, 1158a10-15, 1159b15-16, 1164a2 ff.) or matrimonial (NE 1162A22 ff.) cases of pleasure friendships. I do not think though that these cases should function as the main examples of pleasure friendships. Aristotle also admits that love resembles friendship because "the lover is eager to share the life of the loved one, although not in the most proper way but in a sensuous manner." (EE 1245a25-6) In this case, however, Aristotle makes a crucial distinction between this kind of relationship with friendship and other ones. Love resembles friendship in that the lovers want to share their life with one another, but their attraction is focused on sensuous pleasure. We should not claim, however, that either the passages in the Nicomachean Ethics, or the one in the Eudemian Ethics, reflect more deeply Aristotle's view of pleasure friendships than in other cases where two people may enjoy each other's company in a different way (contra Nehamas, 2010: 231).

${ }^{19}$ Concerning pleasure friendships, commentators of Aristotle usually understand this kind of relationship in the sense of amusing companions (Pakaluk 2005: 267), people who enjoy each other's company (Bostock 2000: 169), drinking companions (Cooper 1999: 318), or even squash partners (Broadie \&Rowe 2002: 58).
} 
doing various things ${ }^{20}$ together. Aristotle also implies that they share their life and time with people who are similar ${ }^{21}$ to them in that they both enjoy these activities. As we will see in the answers of questions 2(a) and 2(b), it really matters that these activities should be valuable enough so that the VA will choose to take part in them. They are not, of course, as valuable as the pleasures of contemplation and virtue, but, as we have already seen, it is quite uncommon for the VA to find another agent who ranks these activities as the highest in his axiological scale. Let us proceed now to answer question $(2 \mathrm{a})$.

I will first remind the reader question (2a): in what way can certain pleasant activities bind together people who are axiologically different? In order to answer this question, we must explore deeper into the nature of these activities, and, therefore, their corresponding pleasures. Now the pleasures that we have seen at $N E$ 1172a3-8 (dice, hunting, etc.) along with other ones, for example, as Broadie says, those of "...say, debate and conversation, of friendship, of sport, of rule-governed play in general, of the arts, of designing things well and crafting them..." $(1991,317)$ can, as she goes on to add "and should be objects to which we are drawn by pre-reflective inclination, having through culture, an affinity with them like a hungry animal's affinity with its food" (1991, 317). In my paper I was deeply influenced by Broadie in taking her examples of pleasures, and the ones I use as indicative of what she calls "cultured pleasures" (p. 317).

Specifically, Broadie's idea that we just saw in the quoted passage is useful for the purposes of our endeavor. Namely, these "cultured pleasures" can work as common ground between the VA and his pleasant friend in that they both enjoy these activities which are not valuable just for one of them, but for both, since, as Broadie says, people have a natural sympathy or affinity towards them through culture. The point is that even if the VA's friend is not completely virtuous, the former can still desire the latter in terms of being similar in that they both enjoy certain cultured activities. What remains now is to answer question $(2 b)$.

This question has to do with the differences between the VA and his pleasant friend. I will suggest that the difference between them has to do with: (a) why each one enjoys these activities, and, (b) each one's attitude toward these activities. In order to understand (a), let us consider each friend in turn. The VA will enjoy these activities as being part of the good life and will probably consider, especially some of them, such as music and involvement in sports, as a vehicle through which he may practice and sustain the virtues. For instance, at Pol. VIII.5 1339b13-15, Aristotle

\footnotetext{
${ }^{20}$ The activities that the agents share with each other may also have to do with music (NE 1175b3-5), the theatre (NE 1175b12), and athletic activities (Pol. VII.12 1331a36, VIII.3 1338b6-7)

${ }^{21}$ For the idea that, similar agents are attracted to each other, see Aristotle's Rhetoric 1371b12-17. For more on this argument see: Vakirtzis (2018), "Similarity, Pleasure, and the Explanation of our Choices of Friends" (unpublished manuscript).
} 
says that music ${ }^{22}$ is valuable because it promotes education, provides amusement ${ }^{23}$, and is the proper way to spend one's leisure time. He develops these ideas more fully at Pol. VIII.3 1337b281338a13 and throughout Pol. VIII.5. Because of the close connection between well-being and leisure (Pol. VIII.3 1337b28-1338a13), it is this last role of music that is most essential.

On the other hand, we also understand that our involvement in some sort of physical training will benefit the health of the body. Aristotle knows this, of course, and he therefore says that the city should provide gymnasia and physical training (Pol. VII.12 1331a36, VIII.3 1338b6-7) for its citizens. He is critical, however, of the way athletes are trained (Pol. VII.16 1335b5-7, VIII.4 1338 b9-11). Specifically, he says that the city should forbid the somewhat excessive and distorted physical development that helps athletes triumph in the contests in which they participate but impedes military fitness.

I have to note here that there is a common idea that lies beneath the examples of music and athletic activities that we just saw. In the case of music, for instance, we may imagine the VA engaging into activities such as, playing a musical instrument, attending jazz festivals or classical music concerts, because they are part of the good life, and because they are beneficial for his soul's virtuous condition. Most of all, we could say, he does not value these activities as the most essential in his life. Instead, virtuous activity (or rational activity) is the most highly valued activity in his life, and, of course, the most pleasant.

Now, his pleasant friend enjoys these activities as well. But there is an important dissimilarity concerning his justification of enjoyment and that of his virtuous friend's. That is, a pleasant friend is probably someone who has formed some good habits of character in enjoying these activities. But the fact that he has formed some good habits does not mean that he is completely good, as his virtuous friend is. He might value one (or all) of these activities because he considers them to be as the most valuable in his life. Specifically, he could be a professional athlete, or a teacher of piano, or the violin. Therefore, he will not value these activities as part of the good and eudaimon life as the VA does, and this is reflected on his attitude towards these activities (b) as well, as we will see in what follows.

Now, the attitude of each agent towards these activities is an additional level of dissimilarity between them. The difference between them rests on how excessively each one engages in them. It is obvious that the VA will not consume himself in, say, playing a musical instrument for 8 hours a day or training for several hours in the palaestra. These are noble activities, but he will take part in them in an intermediate fashion: he will devote to each activity its due time without excess. On the

\footnotetext{
${ }^{22}$ For more details on the benefits of music see, Kraut, 2002: 38, 81, 198-199, p. 201, n.22, 202, 207, 237.

${ }^{23}$ There are, of course, other benefits of music as well, as, for example, to purification (Pol. VIII.7 1341b38$41)$, and the fact that it contributes, in some way, to wisdom (1339a25-26).
} 
other hand, the VA's pleasant friend will have a more immoderate attitude towards these activities. He could be a very good athlete who participates in athletic contests, or a very good teacher of classical guitar. In this way though, he would be devoting too much time in these activities. This means that he considers these activities as the most pleasant and valuable in his life.

The bottom line then is that the two pleasant friends agree on the fact that they both enjoy these activities, but they disagree on the why they enjoy them which is then reflected on each one's attitude towards them. This shows that the VA enters a pleasure friendship without changing his character; without altering, in other words his axiological hierarchy.

Before closing this section and proceed to the conclusion of the present paper, I briefly want to refer to Sarah Broadie once more. She says that the fact that someone develops the ability to value these cultured pleasures is part of the development of moral virtue (1991, p. 317). She goes on to add, however, that it is not necessary for someone to be virtuous ${ }^{24}$ in order to enjoy these activities, and that someone with a defective character could enjoy them as well. In addition, one's enjoyment -especially the VA's- is not that different, after all, from those who have a defective character (1991, p. 317).

I am in partial agreement with Broadie. ${ }^{25}$ The reason for this is that, in our case, even though the VA and his pleasant friend both enjoy the same cultured activities, they are not doing so for the same reasons, or with the same attitude. Moreover, these dissimilarities between them reveal exactly their difference in character. I want to highlight though the fact that we will not judge the VA for his character from the fact that he feels pleasure from these cultured activities. What we must really pay attention to is that he feels pleasure from doing virtuous actions, or, to put it another way, the virtuous activity of his soul. But the fact that he also enjoys certain worthy activities along with another agent, who is not completely virtuous like himself, allows him to form a pleasure friendship with him that he values enough so as to want to be part of it.

\section{Conclusion}

In this paper, I presented an argument with the purpose of defending Aristotle against the jeopardizing effects of the argument at $N E$ 1158a22-27. In this passage, Aristotle argues, roughly, that the VA will avoid friendships based on utility but he will pursue friendships with people who

\footnotetext{
${ }^{24}$ Brodie says: "to be established in virtue" $(1991,317)$. I take her to mean an agent who is completely virtuous in an Aristotelian way.

${ }^{25}$ Broadie concludes that it "would be misleading, therefore, to say on this ground that the virtuous person takes pleasure in his virtuous actions." (1991, 317). She examines this issue deeper in the pages that follow ( $317 \mathrm{ff}$.), but I will not try to contribute any ideas to this difficult discussion since there is no need to do so for the present paper.
} 
are pleasant. As we saw, the first, most important, and immediately noticeable issue in this passage is that the VA, someone who is naturally expected to form character friendships with others, wants, to our surprise, to pursue pleasure friendships. The problem though with this kind of friendship is that it is not apt for the VA's axiological hierarchy of goods, since he values virtue and the good, most of all, and not pleasure or utility.

I tried to defend Aristotle against any unpleasant outcomes of this passage by presenting three reasons that would illuminate why the VA would have to be led to such an unanticipated choice. The three reasons had to do with: (1) the rarity of character friendships, (2) the political nature of man, and (3) the similarity between the VA and his pleasant friend in finding certain activities as pleasant, but also their dissimilarity regarding why they find them pleasant, and each one's attitude towards them. With the aid of these three reasons, I hope to have saved Aristotle from a misinterpretation that could have had serious repercussions for his ethical philosophy. In fact, it would have put at risk the status of his moral ideal, namely the good man. But it seems that the good man will find the best possible solution, even when it comes to choose his friends; and this actually shows that he will follow his rational nature, not messing, in this way, with the values that he so diligently and persistently has built in his soul throughout years of moral education.

Andreas Vakirtzis

University of Cyprus

\section{References}

Annas, Julia (1980). Aristotle on pleasure and goodness. Ed. Amelie Oksenberg Rorty. Essays on Aristotle's Ethics, 285-298.

Bostock, D. (1988). Pleasure and activity in Aristotle's ethics. Phronesis 33 (3): 251-272.

Bostock, D. (2000). Aristotle's Ethics. Oxford: Oxford University Press, 2000.

Broadie, Sarah (1991). Ethics with Aristotle. Oxford: Oxford University Press.

Broadie, Sarah and Christopher J Rowe (2002). Aristotle: Nicomachean Ethics. Oxford; New York: Oxford University Press.

Cooper, J. M. (1990). "Political Animals and Civic Friendship.” In Günther Patzig (ed.) Aristoteles' 'Politik'. Göttingen: Vandenhoeck \& Ruprecht, pp. 221-41. Reprinted in Reason and Emotion, 356-376.

Cooper, J. M. (1999). Reason and emotion: Essays on ancient moral psychology and ethical theory. Princeton University Press.

Hadreas, P. (2004). 'The functions of pleasure in Nicomachean Ethics X 4-5', Ancient Philosophy 24: 15567. 
Harte, Verity (2014). The Nicomachean Ethics on pleasure. Ed. Ronald M. Polansky. The Cambridge Companion to Aristotle's Nicomachean Ethics, 288-319.

Hobbes, Thomas (1994). Leviathan, ed. Edwin Curley. Indianapolis: Hackett.

Hobbes, Thomas. (1983). De Cive: The English Version, edited by Howard Warrender. Oxford.

Irwin, T. (1985) Aristotle's Nicomachean Ethics. Indianapolis: Hackett Publishing.

Kullmann, Wolfgang (1991). "Man as a Political Animal in Aristotle.” In David Keyt and Fred D. Miller, Jr. (eds.) A Companion to Aristotle's Politics. Oxford: Blackwell, 1991, pp. 94-117.

Mulgan, R. G. (1974). Aristotle's doctrine that man is a political animal. Hermes, 102 (3), 438-445.

Nehamas, A. (2010). “Aristotelian Philia, Modern Friendship?” Oxford Studies in Ancient Philosophy, 39: 213-247

Pakaluk, M. (2005). Aristotle's Nicomachean ethics: An introduction. Cambridge University Press.

Vakirtzis, A. (2017). "Similarity, Pleasure, and the Explanation of our Choices of Friends". (Unpublished manuscript). 